\title{
O AUTOR COMO ARQUIVISTA: MEMÓRIA, PÓS-MEMÓRIA E ARQUIVO EM "O ESPÍRITO DOS MEUS PAIS CONTINUA A SUBIR NA CHUVA”, DE PATRICIO PRON
}

\author{
THE AUTHOR AS AN ARCHIVIST: MEMORY, POSTMEMORY AND ARCHIVE IN "O \\ ESPIRITO DOS MEUS PAIS CONTINUA A SUBIR NA CHUVA", BY PATRICIO PRON
}

\author{
Carla Carolina Moura Barreto ${ }^{1}$ \\ Tatiana da Silva Capaverde ${ }^{2}$
}

\begin{abstract}
RESUMO: $O$ presente trabalho tem como principal objetivo analisar o romance autoficcional $O$ espirito dos meus pais continua a subir na chuva (2011), de Patrício Pron, a fim de pensar as relações entre memória, pós-memória, esquecimento, ficção e arquivo. Partindo disso, busca-se compreender como a memória do narrador-personagem é construída e representada, bem como sua relação com o passado histórico argentino, de modo a destacar o caráter arquivístico do romance, que se revela como um arquivo de memórias. Para tanto, utiliza-se como principal base teórica Bergson (2010); Ricoeur (2007); Todorov (2000); Sarlo (2007) e Derrida (2001). Com base nessa discussão teórica, observa-se como memória, história e ficção se unem na obra em um trabalho árduo de rememoração, de reconstituição e de reinvenção da vida e como o narrador, através de seu texto, cumpre um "dever de memória", ao transmitir a outros o legado de seus antepassados.
\end{abstract}

Palavras-chave: Memória; pós-memória; ficção; arquivo; ditadura militar argentina.

\begin{abstract}
The main objective of this work is to analyze the autofiction novel O espirito dos meus pais continua a subir na chuva [My parents' ghost keeps rising in the rain] (2011), by Patrício Pron, in order to think about the relationships between memory, postmemory, forgetfulness, fiction and archive. Starting from that point, we try to understand how the character-narrator's memory is constructed and represented in the work, as well as its relationship with the historical past of Argentina, so as to highlight the features of archive found in the novel, which unfolds as an archive of memories. To do so, this work's main theoretical bases are Bergson (2010); Ricoeur (2007); Todorov (2000); Sarlo (2007) and Derrida (2001). Based on this theoretical discussion, it has been observed how memory, history and fiction come together in that book through a hard effort of remembrance, reconstitution, and reinvention of life, and how the narrator, by means of his text, fulfills a "duty of memory" by transmitting to others the legacy of his ancestors.
\end{abstract}

Keywords: Memory; postmemory; fiction; archive; military dictatorship in Argentina.

\footnotetext{
${ }^{1}$ Mestre em Letras pelo Programa de Pós-Graduação em Letras da Universidade Federal de Roraima - UFRR.

${ }^{2}$ Doutora em Estudos de Literatura pela Universidade Federal Fluminense - UFF. Professora dos cursos de Graduação e Pós-graduação em Letras da Universidade Federal de Roraima - UFRR.
} 
RECORDAR: Del latin re-cordis, volver a pasar por el corazón. (El libro de los abrazos, Eduardo Galeano)

Eduardo Galeano inicia El libro de los abrazos (1989) nos apresentando sua definição da complexa palavra Recordar, termo que está intimamente ligado à memória, à lembrança. Em um único e belíssimo verso, Galeano nos define poeticamente o termo e nos evidencia a essência da memória: o movimento. $\mathrm{O}$ ato de recordar faz alusão a um movimento temporal, uma vez que consiste em trazer de volta à memória imagens de experiências já vividas, isto é, recordar é retornar, é "refazer, reconstruir, repensar, com imagens e ideias de hoje, as experiências do passado" (BOSI, 1994, p. 55), de maneira a revê-lo, (re)senti-lo e reinventá-lo. Desse modo, a lembrança de algo anterior invade o tempo presente, mesclando as percepções do vivido com as percepções do que se vive atualmente, como destaca Bosi (1994):

[...] a memória permite a relação do corpo presente com o passado e, ao mesmo tempo, interfere no processo "atual" das representações. Pela memória, o passado não só vem à tona das águas presentes, misturando-se com as percepções imediatas, como também empurra, "desloca" estas últimas, ocupando o espaço todo da consciência. A memória aparece como força subjetiva ao mesmo tempo profunda e ativa, latente e penetrante, oculta e invasora. (pp. 46-47)

Elegemos o texto de Galeano como epígrafe deste trabalho porque ele se configura como um excelente ponto de partida para refletir sobre a complexidade do tema da memória, nosso principal foco. A memória consiste em um tema amplo que vem sendo constantemente debatido em diversos campos do saber, sob distintas perspectivas, sendo seu conceito considerado, tomando as palavras de Le Goff (2013), crucial. Henri Bergson, em Matéria e memória (1896), afirma que a memória "prolonga o passado no presente" (BERGSON, 2010, p. 247) tendo, portanto, como função primeira "evocar todas as percepções passadas análogas a uma percepção presente, recordar-nos o que precedeu e o que seguiu, sugerindo-nos assim a decisão mais útil” (BERGSON, 2010, p. 266). Destarte, a memória, de forma bem geral, nos remete à capacidade de armazenar fatos ocorridos em um tempo passado que, a qualquer momento, poderão ser evocados, selecionados e sistematizados, evidenciando o deslocamento temporal mencionado a priori, o retorno do passado ao presente.

Beatriz Sarlo, que também debate as complexidades da memória e sua relação com o passado, nos afirma que esse retorno das imagens-lembranças ao nosso consciente é algo conflituoso, soberano e incontrolável, uma vez que a lembrança surge ainda que não a tenhamos convocado, bem como não desaparece por decisão de nossa inteligência. De fato, a lembrança frequentemente se apresenta de modo involuntário, muitas vezes acionada por um gatilho, como: um perfume, um lugar, uma música, uma poesia, uma palavra e até mesmo um gesto, evidenciando a nós, sujeitos, que não possuímos controle sobre nossas memórias, pois, quase sempre, as coisas que mais gostaríamos de esquecer são as que melhor nos recordamos e, por outro lado, as que devemos nos recordar, nem sempre permanecem em nossa memória.

Por se tratar de uma representação presente de uma coisa ausente (RICOEUR, 2007), a fidelidade da memória torna-se suspeita, passando a ser vista como pouco confiável, já que "ela 
é o nosso único recurso para significar o caráter passado daquilo de que declaramos lembrar" (RICOEUR, 2007, p. 40). Segundo Ricoeur (2007):

Enquanto passada, a coisa lembrada seria pura phantasie, mas enquanto dada de novo, ela impõe a lembrança como uma modificação sui generis aplicada à percepção; sob esse segundo aspecto, a phantasie poria em suspenso a lembrança, a qual seria, por causa disso, mais simples que o fictício. Teríamos, assim, a sequência: percepção, lembrança, ficção. (p. 65)

Sendo assim, para Ricoeur (2007), não podemos deixar de considerar as "ciladas do imaginário" ao tratar de memória, já que as imagens-lembranças se entrelaçam às alucinações da imaginação, movimentando-se de acordo com as necessidades da fabulação. Desse modo, além de movimentar-se do passado ao presente, a memória movimenta-se da verdade estrita a uma verdade fabulada, como bem destaca Souza (2010).

Além disso, conforme afirma Pollak (1992), a memória é seletiva, portanto, armazena, mas também exclui, imagina e relembra, e tudo isso é o resultado de um trabalho de organização. Toda recordação passa por esse processo e, por mais nítida que possa parecer a lembrança de um fato antigo, essas imagens jamais retornarão da mesma maneira e jamais corresponderão totalmente à realidade, uma vez que as lembranças que retornam são apenas representações distorcidas e fragmentadas do real, sendo os momentos vividos recordados, mas também escolhidos, esquecidos e fantasiados, o que explicita o caráter ficcional de toda rememoração.

Ao tratar da relação memória-esquecimento, Ricoeur (2007) afirma que o esquecimento é deplorado, como o envelhecimento e a morte, posto que a ele é atribuído o apagamento dos rastros, tornando-se, assim, temido e visto como uma ameaça à memória. Em vista disso, uma luta contra o esquecimento é travada e as lembranças são buscadas e preservadas. Mesmo o esquecimento carregando essa noção negativa, sua relação com a memória é fundamental, sendo ele elemento básico para o seu funcionamento. Tzvetan Todorov, em Los abusos de la memoria (1992), conferencia proferida em Bruxelas, afirma que memória e esquecimento não se opõem em absoluto, pelo contrário, a memória é uma interação entre ambos, isto é, esquecimento e memória são faculdades complementares das quais necessitamos. Segundo o autor:

El restablecimiento integral del pasado es algo por supuesto imposible (pero que Borges imaginó en su historia de Funes el memorioso) y, por otra parte, espantoso; la memoria, como tal, es forzosamente una selección: algunos rasgos del suceso serán conservados, otros inmediata o progresivamente marginados, y luego olvidados. Por ello resulta profundamente desconcertante cuando se oye llamar "memoria" a la capacidad que tienen los ordenadores para conservar la información: a esta última operación le falta un rasgo constitutivo de la memoria, esto es, la selección ${ }^{3}$. (TODOROV, 2000, p. 16)

\footnotetext{
3 "O restabelecimento integral do passado é algo certamente impossível (mas que Borges imaginou em sua história de Funes o memorioso) e, por outra parte, espantoso; a memoria, como tal, é forçosamente uma seleção: alguns rasgos do acontecimento serão conservados, outros imediata ou progressivamente marginados, e logo esquecidos. Por isso resulta profundamente desconcertante quando se ouve chamar "memória" a capacidade que têm os computadores para conservar a informação: a esta última operação falta um rasgo constitutivo da memória, isto é, a seleção." (TODOROV, 2000, p. 16, tradução nossa)
} 
Todorov, como muitos teóricos, reforça o caráter seletivo e infiel da memória, mas também explicita a importância desse processo de "triagem de memórias", valorizando essa seletividade. Jorge Luis Borges, com seu conto Funes, el memorioso ${ }^{4}$ (1944), nos demostrou, através da literatura, quão importante é essa seleção ao especular como seria uma memória absoluta. Com a leitura do conto borgeano, percebemos que Borges compreendia que o esquecimento é uma dádiva. Para ele, assim como para Todorov (2000), a recuperação do passado é indispensável, no entanto, isso não significa que o passado deve reger o presente. É necessário, também, esquecer.

Devido à correlação entre memória e esquecimento, que resulta na instabilidade da memória, o sujeito, há muito tempo, tem buscado preservar suas lembranças e uma das formas que encontrou de registrar o passado é mediante o exercício da arte da memória através da escrita. Segundo Bernd (2018), a escrita surge como uma forte aliada na tarefa de representar, conservar e difundir memórias. Para ela, o ser humano possui uma necessidade de transmitir, de deixar seus rastros, seus traços, sua história e encontra no ato da escrita um meio de difundir seu legado, deixar as "marcas de sua passagem pela terra" (BERND, 2018), na tentativa de resistir ao esquecimento. Com isso, com cada vez mais frequência, aquele que rememora tem buscado produzir textos a partir de suas lembranças, de modo a registrar, reconstruir e reinventar o real, partindo do que a crítica literária denomina como escritas de si ou escritas memorialísticas.

Dessa maneira, diversas escritas centralizadas no "eu" têm surgido na contemporaneidade com o intuito de arquivar, rever e repensar o passado (autobiografias, testemunhos, memórias, autoficções, etc). Com esses textos, que em sua maioria são construídos a partir da rememoração, temos uma espécie de arquivamento e perpetuação de memórias e pós-memórias que, de alguma forma, poderão contribuir tanto sobre aquele que escreve, quanto sobre aquele que lê. Patricio Pron, Julián Fuks, Laura Alcoba, Maria Pilla, Chico Buarque e Bernardo Kucinski são alguns importantes nomes da ficção contemporânea que, através de textos de cunho autobiográfico, arquivaram, ficcionalizaram e puseram em movimento suas memórias sobre períodos históricos bastante significativos- como as ditaduras argentina e brasileira-, de modo a possibilitar a gerações posteriores uma visão e uma compreensão do nosso passado e de nossa história.

Compreendemos que essa conservação e perpetuação das memórias individual e coletiva é de grande importância para a sociedade que, por vezes, mais esquece do que lembra. Através dos registros mnemônicos, guarda-se, coleciona-se e transmite-se saberes, experiências e crenças, que poderão ser acessados por inúmeros leitores, de modo a impulsionar novas descobertas e suscitar discussões. Desse modo, com isso, podemos afirmar que esses textos podem ser considerados arquivos e seus autores como arquivistas. Partindo disso, memória e arquivo passaram a ser vistos pela crítica como conceitos indissociáveis, visto que o arquivo está impregnado de práticas e sentidos mnemônicos, constituindo-se de um lugar de referência que potencializa a transmissão de memórias e histórias.

\footnotetext{
${ }^{4} \mathrm{O}$ conto borgeano narra a história de Ireneo Funes, um jovem de 19 anos que, após cair de um redomão, fica paraplégico e adquire uma memória prodigiosa, passando a rememorar o passado constantemente. O personagem adquiriu a capacidade de tudo lembrar-se ou nada esquecer-se e, com isso, passou a viver apenas de suas memórias, sendo privado da capacidade de pensar. Sua memória somente registrava tudo o que lhe ocorria, sem dar espaço a um real raciocínio dessas recordações armazenadas, uma vez que "pensar é esquecer diferenças, é generalizar, abstrair”. (BORGES, 1974, p. 490, tradução nossa).
} 
Segundo Assmann (2011), o arquivo consiste em um armazenador coletivo que desempenha papeis fundamentais: conservar, selecionar e tornar acessivel. Conforme a autora, o que condiciona sua existência "são sistemas de registro que agem como meios de armazenamento externos" (p. 367), como a escrita que "removeu a memória de dentro do ser humano e a tornou fixa e independente dos portadores vivos" (p. 367). O arquivo foi criado "utilizando-se uma escrita materialmente fixável que codifica informação de modo que ela possa ser lida pelas gerações vindouras" (ASSMANN, 2011, p. 26), funcionando, portanto, como um lugar de memória ${ }^{5}$ que guarda, armazena, esclarece, revela, tornando um conteúdo individual, coletivo.

No atual cenário da literatura contemporânea latino-americana, temos a obra $\mathrm{O}$ espírito dos meus pais continua a subir na chuva ${ }^{6}$, (2011), do escritor e jornalista argentino Patricio Pron, como um exemplo de narrativa de cunho autobiográfico que se configura como um arquivo de memórias e pós-memórias. Este consiste em um texto híbrido construído a partir da rememoração de um narrador assombrado pelo passado opressor de seu país, a Argentina. A obra é composta por quatro capítulos e um epílogo, possui uma estrutura fragmentária de parágrafos numerados e vários elementos dos gêneros autobiografia, romance, testemunho e romance policial.

O livro tem início quando um jovem escritor argentino que vive na Alemanha retorna à sua cidade natal para reencontrar o pai, um jornalista e ex-militante de uma organização peronista de luta armada, que está à beira da morte. $\mathrm{O}$ narrador, nesse retorno, tenta retomar o contato com a memória familiar, a casa, os pais, os irmãos. Durante sua estadia em seu antigo lar, ele passa a revolver a biblioteca da família e, ao ter contato com alguns materiais arquivados pelo pai, o protagonista se depara com uma série de recortes de jornais, mapas, fotografias e documentos que dão conta do desaparecimento e assassinato de um habitante desconhecido daquela região, chamado Alberto José Burdisso. A partir daí, o filho inicia uma busca detetivesca na tentativa de desvendar o que ocorreu com aquele desconhecido e o que levou seu pai a compilar tantas informações sobre o tema. Com isso, o narrador realiza um trabalho de investigação que irá abalar seu emocional, acionando memórias adormecidas que dizem respeito não somente a ele e sua família, mas, também, a uma coletividade, uma vez que não tarda para que o leitor descubra que há um elo entre essa história e a sangrenta história da ditadura militar argentina.

A narrativa de Pron é construída a partir da memória do protagonista e, por sua vez, versa sobre o tema da memória, sendo o processo rememorativo sempre colocado em debate. $\mathrm{O}$ texto tem início à la Funes, sendo marcado pela palavra lembrar: "me lembro dos quartos das duas casas em que morei, me lembro da neve entrando nos meus sapatos [...], me lembro da porta do consultório do psiquiatra que me atendia, mas não me lembro do seu nome nem como cheguei até ele" (PRON, 2018, p. 9, grifo nosso), enfatizando, assim, o caráter memorialístico do texto. Todos os fatos narrados são produto de uma rememoração do protagonista, que tenta recuperar o passado por meio da memória e relatá-lo, no entanto, o narrador coloca a convicção dessas memórias em constante suspeita, ao afirmar que suas lembranças são vagas e imprecisas.

O autor dessas memórias não é nomeado, todavia, não precisamos de um nome para constatar que Patrício Pron ficcionalizou algumas de suas memórias, concedendo ao texto um

\footnotetext{
${ }^{5}$ Termo cunhado pelo historiador Pierre Nora (1993).

${ }^{6} \mathrm{O}$ título da obra consiste em um verso extraído do poema I Fellowed Sleep, de Dylan Thomas. (My fathers' ghost is climbing in the rain)
} 
caráter autobiográfico ${ }^{7}$. Pron, que assim como o narrador também é filho de ex-militantes argentinos e também viveu durante muito tempo na Alemanha, mescla suas memórias individuais às memórias ficcionais, ficcionalizando-se. $\mathrm{O}$ autor insere em seu texto ficcional muitos fatos autênticos, como o desaparecimento e morte de José Alberto Burdisso e de sua irmã Alicia Raquel Burdisso ; a luta dos pais como militantes; a identidade do pai de Patricio Pron, Chacho Pron; e suas memórias de infância. No entanto, em meio a fatos históricos e verídicos, Pron adiciona ficção, como ele próprio alerta no epílogo do livro:

Embora os fatos narrados neste livro sejam essencialmente verdadeiros, alguns deles são produto das necessidades do texto ficcional, cujas regras são diferentes das regras de gêneros como o testemunho e a autobiografia; nesse sentido, gostaria de mencionar aqui o que disse uma vez o escritor espanhol Antonio Muñoz Molina, como lembrete e advertência: "Uma gota de ficção mancha tudo de ficção". (PRON, 2018, p. 158)

Assim sendo, o autor se autoficcionaliza, isto é, se transforma em um personagem de sua própria obra, de maneira a dissolver as fronteiras entre o real e o fictício e a construir uma representação de si mesmo. A obra de Pron é declaradamente uma ficção, no entanto, uma ficção que contém fatos históricos, biográficos, não se configurando como um romance puro, mas sim como um texto autêntico que contem gotas de ficção. Desse modo, partimos da ideia de que a obra de Pron se configura como uma autoficção, uma ficção de acontecimentos e fatos reais (DOUBROVSKY, 1977), uma vez que encena um "eu", joga com o real e o imaginário entrelaçando os gêneros referencial e ficcional, não sendo, portanto, um texto totalmente autobiográfico, tampouco totalmente fictício, instaurando-se, assim, no "entre-lugar".

A obra de Patricio Pron é composta por um série de gêneros não literários, como listas (remédios, livros, nomes próprios), receita de comida, enredos de filmes, documentos e transcrições de entrevistas e artigos de jornais, o que atribui à obra um estilo não muito convencional. Os artigos inseridos no livro pertencem, em sua grande maioria, ao jornal El trebol Digital e são transcritos e devidamente referenciados pelo narrador durante grande parte do capítulo $\mathrm{II}^{10}$. É através desses textos jornalísticos que o protagonista e nós leitores tomamos conhecimento dos detalhes acerca do desaparecimento de Alberto Burdisso. As notícias, que datam de junho a julho de 2008, nos apresentam cada passo da investigação do caso, desde o desaparecimento de Burdisso, até o desvendamento do mistério e a prisão dos culpados. Esses textos, que são autênticos e podem ser encontrados no site do jornal ${ }^{11}$, atribuem à obra um valor histórico, biográfico, levando o leitor a questionar-se sobre o caráter ficcional e/ou documental da obra, além, claro, de demonstrar uma aproximação ao gênero jornalístico (muito presente na vida do autor, que é jornalista e filho de jornalistas).

Além disso, a narrativa de Pron flerta com o gênero policial ao apresentar um enigma a ser investigado, trazendo elementos como vítimas, crimes, mistérios, detetives, investigações e inquietações. Com isso, temos uma narrativa que é duplamente híbrida: contém traços de

\footnotetext{
${ }^{7}$ O próprio autor nos revela isso no epílogo do livro.

${ }^{8}$ Alicia Raquel Burdisso foi uma jornalista, estudante de Letras e militante durante a ditadura militar argentina sequestrada na saída de seu trabalho, em San Miguel de Tucumán, em 1977. Alicia nunca foi encontrada.

${ }^{9}$ Conceito comumente utilizado nos Estudos Culturais. Serge Doubrovsky utiliza o conceito de entre-lugar para se referir ao espaço entre autobiografia e romance.

${ }^{10}$ A transcrição feita pelo narrador preserva os erros tipográficos e a sintaxe errática do texto original.

11 <eltreboldigital.com.ar>
} 
distintos gêneros (autobiografia, romance, testemunho, gênero policial) e é composta pela presença de extratos de uma série de gêneros não literários.

Em alguns momentos do texto, como dito a priori, Pron questiona a qualidade de suas recordações, enfatizando o caráter dúbio de sua memória. Segundo o narrador, suas memórias possuem interpretação e invenção, principalmente por se tratarem de recordações de alguém que está sempre sob o efeito de fortes medicamentos e que, portanto, são falhas, o que nos atesta que há uma imbricação entre memória, esquecimento e ficção: "[...] É claro que havia uma dose indecifrável de interpretação e talvez de invenção em tudo que eu recordava [...]" (PRON, 2018, p. 138).

Além disso, o narrador cria listas a fim de impedir que certas recordações sejam esquecidas. Isso é feito desde o momento em que ele percebe que está perdendo grande parte de suas memórias: "[...] tentei fazer uma lista das lembranças que tinha de mim mesmo e dos meus pais, para que a memória, que eu já tinha começado a perder, não me impedisse de lembrar de duas ou três coisas que eu queria guardar para mim [...]" (PRON, 2018, p. 36-37), até o retorno à casa dos pais: "eu tinha que fazer um inventário de tudo o que eu estava vendo na casa dos meus pais para não esquecer de nada” (PRON, 2018, p. 27).

A memória fragmentada do narrador é representada graficamente no texto através de parágrafos fragmentados e numerados. Nessa organização, a obra apresenta certa desordem na sequência numérica dos parágrafos, isto é, não há uma sequência lógica, alguns números são esquecidos, deixando vazios, e outros são duplicados. O primeiro capítulo é o que mais apresenta essa irregularidade, ao possuir diversas lacunas entre os números, de modo a representar, portanto, lacunas na narração e na mente do narrador. Vejamos um esquema que representa a organização do Capítulo I:

\section{Capítulo I}

1-2-4-5-6- 7-9-10-11-12-13-14-15-18-20-21-23-24-25-26-27-29-30-32-35-36-38-39-42-4546-

Os trechos em destaque nos mostram essa constante desorganização do capítulo, marcado pelos mencionados vazios. Esses vazios numéricos representam os vazios da memória do narrador, que se vê confuso durante seu retorno à sua cidade natal e que se mostra dotado de uma memória decadente, fragilizada pelo tempo, pelos remédios e pelo trauma. Durante grande parte do capítulo, ele demonstra incertezas diante de suas colocações. Ao descrever um encontro curioso com um jogador de futebol, o narrador manifesta certa desconfiança em relação à veracidade daquele episódio, já que reconhece ser portador de amnésia. Segundo ele:

[...] aquele encontro, que aconteceu realmente e que, portanto, foi verdadeiro, pode ser lido aqui simplesmente como falso, já que [...] eu estava tão desorientando e preocupado que podia e ainda posso desconfiar dos meus sentidos, que naquela época talvez interpretassem erroneamente um fato verdadeiro [...]. (PRON, 2018, p. 21)

O capítulo II apresenta poucas lacunas, nele percebemos apenas um espaço vazio e uma duplicação numérica. Vejamos: 


\section{Capítulo II}

$1-[\ldots]-25-\mathbf{2 6 - 2 6}-27-28-29-30-[\ldots]-66-\underline{67-69-70-71-72}$

Como podemos perceber, a estrutura desse capítulo apresenta-se de maneira mais ordenada que a do anterior. Isso pode ser resultado do fato de que essa parte é construída, em sua maioria, por transcrições de arquivos pertencentes à pasta do pai, isto é, textos alheios, os quais predominam mais que a narração de suas memórias pessoais.

No capítulo três, temos o retorno dessa desorganização que, apesar de surgir com menos frequência em relação ao primeiro capítulo, surge, agora, de modo mais desregrado. Observemos:

\section{Capítulo III}

1-3-3-4-5-7-8-9-10-[...]-19-20-21-22-22-23-24-22-11-9-26-3-22-30-31

Essas lacunas surgem devido a uma ocorrência que toma grande parte dessa terceira parte do relato: um episódio de febre, delírios e sonhos, que prejudicam com mais intensidade a mente do narrador, que se vê demasiadamente confusa diante de tantas descobertas e recordações.

Por fim, no capítulo IV, ainda temos a presença desse desalinho:

\section{Capítulo IV}

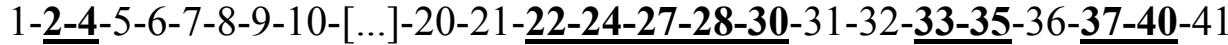

Aqui, percebemos que ainda há certa desorganização, mas ela surge com menos intensidade. Isso ocorre devido ao fato de o narrador se mostrar um pouco mais lúcido nesse capítulo. Nessa parte, ele tem êxito na recuperação de suas memórias e compreende a importância delas para o mundo. Com isso, ele se propõe a escrever suas recordações, arquivando-as, isto é, narrando-as em um romance que servirá para que outros possam ter acesso a elas e formular suas próprias conclusões sobre esse passado individual que é, também, coletivo, histórico. Além dessa estrutura incomum, a obra de Pron apresenta muitas redundâncias, espelhamentos, frases e ideias repetidas, confusas, fato que, mais uma vez, nos revela a confusão mental do narrador e a instabilidade de sua memória, de suas percepções.

Como vimos, há uma relação intrínseca entre memória e esquecimento. As lembranças podem gerar imagens que não condizem com o evento real, pois o indivíduo não somente recorda, mas também imagina, fantasia, interpreta e inventa o passado. Isso ocorre porque a 
memória não pode ser extraída pura, clara, consistente, ela é um processo contínuo, composto por uma coerência entre o modo de narrar e a articulação rememorativa (RICOEUR, 2007), e é isso o que o narrador nos evidencia ao enfatizar a inconsistência de suas memórias. Ao tocar nessa questão, Pron, através de seu texto, chama a atenção para a complexidade do processo rememorativo, apontando a dificuldade de lembrar e escrever memórias. Assim, por meio dessa narrativa, nós, leitores, temos acesso ao complexo processo de rememoração do narrador, bem como à ideia do modo que esse autor-narrador se coloca diante de suas recordações.

Além de estar ciente desse caráter frágil de sua memória, o narrador percebe a urgência em buscar, arquivar, registrar e perpetuar as lembranças que ao longo do romance vão sendo recuperadas. Em determinado ponto da narrativa, o protagonista se propõe a resgatar memórias antigas, que ele percebe como relevantes de serem postas em movimento, se dispondo a escrever sua história, de maneira a torná-la pública e acessível a outras pessoas:

[...] cheguei à conclusão que um bom caminho seria escrever um dia sobre tudo o que tinha acontecido comigo e com meus pais, e esperar que outras pessoas se sentissem provocadas e começassem suas próprias investigações sobre uma época que para alguns de nós parecia não ter acabado. (PRON, 2018, p. 147)

A época a que o narrador se refere corresponde à década de 1970, período em que se instaurou a mais sangrenta ditadura civil-militar na Argentina. $\mathrm{O}$ regime militar argentino teve início na madrugada do dia 24 de março de 1976, quando uma junta militar composta por membros das forças armadas derrocam o governo constitucional da então presidente Maria Estela Martinez Perón (Isabel Perón). Perón assumiu o governo em 1974, após a morte do marido, Juan Domingo Perón, tornando-se a primeira mulher a ocupar a presidência de um país na América Latina. No entanto, em meio a muitos conflitos sociais durante seu governo (crises sociais, econômicas e políticas), o país sofre uma intervenção militar que se estabelece com o intuito de "restabelecer a ordem, reorganizar as instituições e criar as condições para uma 'autêntica democracia”" (NOVARO; PALERMO, 2007, p. 26).

Com esse Processo de Reorganização nacional, como foi denominado, se estabelece na Argentina um governo extremamente autoritário, violento, censurador e silenciador, levando o país a tornar-se um Estado Terrorista, que passou a violar massivamente os direitos humanos, sendo responsável pelo assassinato, sequestro e tortura de um número significativo de pessoas. Diversos argentinos considerados "subversivos" foram torturados e exterminados, dando início a uma guerra sucia" 12 . O regime considerava como "subversivos" aqueles que discordavam das ideias do governo, como: ativistas sociais, universitários, intelectuais, operários, sacerdotes e todos os que demonstravam "ser inimigo ideológico, ser de esquerda, ser não-argentino, ser judeu ou ser um irrecuperável” (PASCUAL, 2004, p. 50).

Campos clandestinos de detenção e extermínio foram criados e, a cada dia, a perseguição, o terrorismo e a repressão cresciam no país, que se tornou um lugar sombrio, angustiante, como bem descreve Patrício Pron, no romance que aqui analisamos: "[...] vivíamos em um ambiente em que o terror fazia com que os sons e movimentos chegassem até nós com atraso, como se estivéssemos debaixo d'água” (PRON, 2018, p. 104). Denúncias sobre violações dos direitos humanos começaram a surgir constantemente, partindo, principalmente, de

\footnotetext{
${ }^{12}$ Guerra suja, como ficou conhecido o regime adotado em meio a ditadura militar argentina, caracterizado pela violência.
} 
familiares das vítimas desaparecidas e assassinadas. Assim, o povo começou a lutar contra esse sistema, a protestar, a resistir e a criar organizações de oposição e denúncia ${ }^{13}$.

Após muitos conflitos, em 1983, a ditadura militar tem fim e o Estado de direito volta a reinar sobre o país. Todos os generais envolvidos nos crimes da ditadura foram julgados e condenados, posteriormente. No entanto, apesar das condenações e do término da sangria, profundas marcas são deixadas na Argentina e nos argentinos, marcas de dor, de angústia, de trauma, marcas que, infelizmente, reverberam até os dias atuais.

Diante desse passado argentino sombrio, o ato de recordar torna-se fundamental para os sobreviventes. A partir do Nunca más, relatório emitido pela Comissão Nacional sobre o Desaparecimento de Pessoas (CONADEP),- que esclarecia as ações ocorridas durante o regime militar-, os relatos sobre as memórias da ditadura passam a surgir com bastante intensidade. Temos uma diversidade de testemunhos de sobreviventes, familiares de vítimas e militantes expostos através de diversas produções artísticas,- literatura, cinema, teatro, música- e históricas, - produções jornalísticas e historiográficas. Esse trabalho de registro e memória busca, principalmente, manter a presença do tema na memória coletiva, possibilitando revisitações e reflexões, de modo a enfatizar que o que ocorreu não pode e não deve se repetir Nunca más.

Em O espirito dos meus pais continua a subir na chuva temos um relato de memória construído, também, com esse intuito de registrar a fim de arquivar e suscitar debates e reflexões. $O$ narrador, ao ter acesso aos documentos do pai, ex-militante argentino, descobre que seu interesse no caso Burdisso possui uma relação com seu passado e com o passado argentino. O pai foi colega de escola de Burdisso e amigo de sua irmã, Alicia. Chacho Pron interessou-se pelo desaparecimento de seu antigo amigo e decidiu investigá-lo por conta própria, reunindo uma gama de elementos relacionados ao caso. $O$ narrador supõe que o grande interesse do pai em desvendar esse mistério possui relação com Alicia Burdisso, militante que se envolveu na política por influência dele, sem saber que isso custaria a sua vida.

Todos esses acontecimentos, descobertos pelo narrador por meio dos arquivos do pai, funcionam como um gatilho que suscita suas memórias mais dolorosas:

Foi então que tudo que eu tinha tentado esquecer voltou à tona com uma intensidade incomum, e agora não de forma indireta, como as imagens nebulosas de fotografias que eu tivesse reunido só para não precisar olhar para elas. [...] Estava lá, simplesmente, e explicava tudo, explicava o terror que eu instintivamente associava ao passado, como se no passado tivéssemos vivido em um país chamado medo cuja bandeira fosse um rosto desfigurado pelo terror, explicava meu ódio por esse país infantil e por que o abandonei, em um desterro que começou muito antes de eu ir embora para a Alemanha e de tentar, até por fim conseguir, esquecer tudo. (PRON, 2018, p. 130)

O personagem, inicialmente desmemoriado, tem o retorno imediato de lembranças sobre seu passado, que o ajudam a compreender a história dos pais e a ligação dessa história

\footnotetext{
${ }^{13}$ Uma das associações fundadas é a Asociación Madres de la Plaza de Mayo, criada por mães de desaparecidos durante o regime militar. Em 1977, as mães de vítimas da ditadura se reuniram na Plaza de Mayo, em Buenos Aires, para exigir notícias de seus filhos desaparecidos e sequestrados pelo regime. Essas mães "mostraram ao mundo que na Argentina havia milhares de mortos sem sepultura. Elas guardavam consigo essa memória de repressão". (CAPELATO, 2006, p. 69), exigindo justiça. Anos depois, a organização, que manteve o mesmo propósito, tornou-se Abuelas de Plaza de Mayo.
} 
com os casos dos irmãos Burdisso. Tudo estava relacionado ao terror da ditadura militar argentina que assolava o país. Por ser filho de militantes argentinos, o protagonista teve uma vida fora do comum. Ao recordar-se de suas memórias de infância, ele passa a compreender que acontecimentos ligados à ditadura fizeram com que ele jamais tivesse uma família, um lar e uma infância "comum": "Alguma coisa aconteceu com meus pais, comigo e com meus irmãos que fez com que eu jamais soubesse o que era uma casa e o que era uma família, mesmo quando tudo levava a crer que tive ambas as coisas." (PRON, 2018, p. 143). Sua infância sempre foi cheia de restrições, precauções e regras, sendo permeada pelo medo e pela angústia:

Quando eu era menino, tinha ordens de não trazer outras crianças para casa;
quando andava sozinho pela rua, tinha que caminhar em sentido contrário ao
trânsito e prestar atenção se algum carro parasse perto de mim. Eu usava uma
plaquinha no pescoço com meu nome, minha idade, meu tipo sanguíneo e
um telefone de contato: se alguém tentasse me puxar para dentro de um carro,
eu tinha que jogar essa plaquinha no chão e gritar meu nome muitas vezes e o
mais alto que eu pudesse. Era proibido chutar as caixas de papelão que eu
encontrasse pela rua. Eu não podia contar a ninguém nada do que escutasse
em casa [.... Essas regras, que naquele momento voltaram à minha memória
pela primeira vez em muito tempo, tinha o objetivo de me proteger, de
proteger meus pais, eu e meus irmãos em uma época de terror. (PRON, 2018,
pp. 130-131)

Essas regras refletiram na vida adulta do protagonista, que permaneceu reproduzindo automaticamente algumas ações de infância, ainda que não recordasse ou compreendesse o motivo: "[...] quando me lembrei delas [regras], pensei em algo que eu continuava fazendo na Alemanha, quando estava distraído: traçava caminhos imaginários para chegar ao meu destino, sempre andando em sentido contrário ao trânsito.” (PRON, 2018, p. 131). Com isso, percebemos que esse passado do narrador, ainda que adormecido em seu inconsciente, teve reflexo em suas ações rotineiras. Isso nos evidencia que esse personagem ficou profundamente marcado pelos acontecimentos de sua infância, assim como muitos filhos de militantes engajados na luta armada. Assim sendo, ao narrar essas questões, Pron tematiza os impactos da ditadura também sobre os filhos de militantes.

Temos aqui, visivelmente, a presença de um trauma. O narrador mostra-se como alguém ferido, alguém que não conseguiu superar esses episódios da infância; o ambiente sempre hostil de sua casa; a distância do pai; e os relatos de família sobre os desaparecidos e mortos. Com isso, ele opta por esquecer-se desse passado, deixá-lo para trás e, para isso, decide distanciar-se geograficamente de seu país e fazer uso de medicamentos capazes de prejudicar sua memória, adormecendo-as em seu inconsciente. Em determinado momento da narrativa, ao relembrar tudo, o narrador percebe que o desejo de esquecer partia dele próprio e que ele tinha mais motivos para isso do que imaginava: "[...] não foram os remédios que causaram a incapacidade de me lembrar dos eventos da minha infância, mas foram os próprios fatos que provocaram meu desejo de me entupir de remédios e esquecer tudo [...]" (PRON, 2018, p. 131). Nesse momento, o personagem se dá conta de que sua amnésia está ligada a um esforço inconsciente dele próprio, como forma de se autopreservar, de se proteger da dor do trauma.

Durante seu regresso à Argentina, o protagonista empreende uma busca, força propulsora do romance. Ele, que está em busca do pai (figura distante, ausente), passa a escavar seu passado familiar, revelando, no fim, uma busca por memória, justiça, reflexão. Na medida 
em que vai relembrando o passado doloroso da Argentina, como dito anteriormente, o narrador percebe a importância de narrar aquela história para si, para os pais e para outros. Ele compreende que há um dever a cumprir, um dever de memória: escrever, registrar, arquivar e movimentar a memória histórica familiar, de maneira a reconstruir e ressignificar esse passado.

Muitos escritores têm produzido narrativas sobre os desmandos das ditaduras, registrando suas memórias, seus traumas, suas cicatrizes. Esses escritos podem ser considerados como arquivos, uma vez que são textos nos quais são depositados dados, informações sobre um acontecimento histórico significativo, de maneira a evidenciar algumas das situações de repressão e violência a que milhares de pessoas foram submetidas. Esses arquivos que abordam “desastres que marcam o fim do milênio", são considerados por Derrida (2001), como "arquivos do mal: dissimulados, ou destruídos, interditados, desviados, 'recalcados'”. (p. 7, grifo do autor). Derrida, em seu livro Mal de arquivo: uma impressão freudiana (1995), promove algumas discussões sobre a complexidade do arkhé (arquivo) e sua relação com a memória pessoal e histórica a partir da consideração da obra de Freud. Nesse ensaio, o filósofo esclarece:

o arquivo, se esta palavra ou esta figura se estabiliza em alguma significação, não será jamais a memória nem a anamnese em sua experiência espontânea, viva e interior. Bem ao contrário: o arquivo tem lugar em lugar da falta originária e estrutural da chamada memória.

Não há arquivo sem um lugar de consignação, sem uma técnica de repetição e sem uma certa exterioridade. Não há arquivo sem exterior. (DERRIDA, 2001, p. 22, grifo do autor).

Desse modo, segundo o autor, o arquivo não pode se confundir com a memória, posto que a instabilidade da memória é o principal motivo de sua existência. $O$ arquivo é hipomnésico, é documento, é lugar de consignação, é registro de memória que necessita ser arquivada, exteriorizada, rememorada. De acordo com Derrida (2001), há uma pulsão de arquivo, um desejo de conservação, mas simultaneamente há também uma pulsão de morte, uma pulsão arquiviolítica de destruição:

Ela trabalha para destruir o arquivo: com a condição de apagar mas também com vistas a apagar seus "próprios" traços- que já não podem desde então serem chamados "próprios". Ela devora seu arquivo, antes mesmo de tê-lo produzido externamente. Esta pulsão, portanto, parece não apenas anárquica, anarcôntica (não nos esqueçamos que a pulsão de morte, por mais originária que seja, não é um princípio, como o são o princípio do prazer e o princípio de realidade): a pulsão de morte é acima de tudo, anarquivica, poderíamos dizer arquiviolitica. Sempre foi, por vocação silenciosa, destruidora do arquivo. (DERRIDA, 2001, p. 21, grifo do autor)

Assim, essa pulsão de morte "tende assim a destruir o arquivo hipomnésico, quando não a disfarçá-lo, maquiá-lo, pintá-lo, imprimi-lo, representá-lo no ídolo de sua verdade em pintura." (DERRIDA, 2001, p. 23), sendo, portanto, um mal de arquivo. Na ficção, temos essa pulsão de destruição e apagamento de memórias como centro de algumas narrativas, como é o caso do clássico 1984 (1949), de George Orwell. O protagonista da narrativa distópica, Winston, trabalha no chamado Ministério da Verdade e tem como função apagar e falsificar 
registros históricos, a fim de moldar o passado à luz dos interesses do Partido dominante (The Big Brother). Segundo o protagonista:

Todos os registros foram destruídos ou falsificados, todos os livros foram reescritos, todos os quadros foram repintados, todas as estátuas, todas as ruas, todos os edifícios foram renomeados, todas as datas foram alteradas. E o processo continua dia a dia, minuto a minuto. A história se interrompeu. Nada existe além de um presente interminável no qual o Partido tem sempre razão. [...] Depois que a coisa está feita, nunca resta nenhuma prova. A única prova está dentro da minha cabeça, e não tenho certeza de que outro ser humano partilhe minhas lembranças. (ORWELL, 2009, p. 185)

O passado era apagado e modificado pelo Partido distópico apresentado por Orwell, revelando essa "pulsão arquiviolítica" discutida por Derrida. Atos semelhantes foram feitos com frequência ao longo da história por diversos governos que tinham como propósito esconder, fazer calar, direcionar para o silêncio e para o olvido. Na Argentina, por exemplo, tivemos o apagamento e destruição de grande parte dos arquivos concernentes à repressão, praticado pelos militares que desejavam ocultar seus feitos. Tal destruição impulsionou o desejo da população a um "resgate de memórias", o que resultou na construção de múltiplos relatos acerca da ditadura.

Ainda segundo Derrida (2001), a emergência do arquivamento se dá a partir do esquecimento e dessa pulsão de destruição: "Não haveria certamente desejo de arquivo sem a finitude radical, sem a possibilidade de um esquecimento que não se limita ao recalcamento. [...] sem a ameaça dessa pulsão de morte, de agressão ou de destruição" (DERRIDA, 2001, p. 32). Desse modo, a sociedade que, como vimos, vive na linha tênue entre recordar e esquecer, trava uma luta contra o apagamento da memória, buscando arquivá-la.

É partindo disso, que Patrício Pron compreende a urgência e a primordialidade de se escavar o passado e arquivá-lo, revelá-lo ao mundo. Após as lembranças sobre seu passado familiar retornarem à sua mente e ao seu coração por meio da recordação, o personagem questiona-se: "Eu me perguntei o que a minha geração poderia oferecer que estivesse à altura do desespero exuberante e da ânsia por justiça da geração anterior, a dos nossos pais" (PRON, 2018, p. 143), e logo se dá conta da resposta para sua pergunta: a memória. A geração de filhos, nesse momento, tem apenas a memória a oferecer, a memória como arquivo, como ato de recordação, como ato de justiça. $O$ narrador vê na atitude de escavar e arquivar o passado familiar e histórico por meio da literatura uma tarefa fundamental, um dever como filho:

Os filhos são os detetives que os pais lançam no mundo para que um dia retornem e contem a eles a sua história e, assim, eles mesmos possam compreendê-la. Os filhos não são os juízes dos pais, já que não podem julgar de maneira realmente imparcial alguém a quem devem tudo, mas podem tentar colocar ordem em sua história, restituir o sentido que foi apagado pelos acontecimentos mais ou menos pueris da vida e sua acumulação, e depois proteger essa história e perpetuá-la na memória. (PRON, 2018, p. 10, grifo nosso)

E é exatamente isso que o escritor Patrício Pron faz ao publicar $\mathrm{O}$ espirito dos meus pais continua a subir na chuva. Pron, assim como o narrador personagem, arquiva e difunde suas 
memórias, dando visibilidade a uma experiência individual que também diz respeito a uma coletividade, com o propósito de despertar a conscientização em seus leitores e fazê-los conhecerem um pouco a sua história familiar e a história violenta de seu país. Além disso, a escrita de Pron consiste na consequência do medo do esquecimento e da pulsão arquiviolítica, o medo de que a história de luta de seus pais e as injustiças sociais da Argentina sejam esquecidas, apagadas pelo tempo. Desse modo, com sua obra, ele busca auxílio para manter ativa a lembrança, para preservá-la, compreendê-la e, consequentemente, para aliviar-se da dor que perdurou durante anos e que o impulsionou a abandonar seu país.

Além de suas próprias memórias, o narrador nos apresenta o arquivamento, também, das memórias de seus pais, ao recuperar e narrar memórias que não lhe pertencem e, com isso, pratica um ato de pós-memória. O conceito de pós-memória tem se destacado nas discussões em torno do Holocausto e das ditaduras latino-americanas. Ele surge com frequência na obra de Marianne Hirsch e é retomado por outros importantes estudiosos como Sarlo (2007) e Pollak (1992). Segundo Sarlo (2007), baseada nos argumentos de Hirsch, a pós-memória ocorre quando os filhos reconstituem as experiências dos pais, apoiados em suas lembranças, ou seja, quando fatos não experienciados pelo sujeito são reconstituídos por ele. Nesse sentido, a pósmemória possui duas especificidades: 1) Se trata de uma memória vicária e mediada; 2) se trata de uma memória em que estão implicados dois níveis de subjetividade, o que a torna ainda mais distante do "real". Desse modo:

[...] essa memória pode se tornar um discurso produzido em segundo grau, com fontes secundárias que não vêm da experiência de quem exerce essa memória, mas da escuta da voz (ou da visão das imagens) dos que nela estão implicados. Essa memória de segunda geração, lembranças pública ou familiar de fatos auspiciosos ou trágicos. O prefixo pós indicaria o habitual: é o que vem depois da memória daqueles que viveram os fatos e que, ao estabelecer com ela essa relação de posterioridade, também tem conflitos e contradições característicos do exame intelectual de um discurso sobre o passado e de seus efeitos sobre a sensibilidade. (SARLO, 2007, p. 92)

O narrador assume a voz dos pais e torna-se um memorialista de segundo grau, ao nos apresentar memórias pautadas em informações que, segundo ele, "eu só conhecia vagamente, através do relato dos meus pais e da minha própria percepção do medo" (PRON, 2018, pp. 135136). Durante grande parte do capítulo IV, o personagem se dedica a descrever os relatos memorialísticos dos seus pais, de modo a apresentar ao leitor um retrato daquela realidade e suas consequências. Em determinado momento, ele narra o destino da organização da qual os pais faziam parte, a Guardia de Hierro:

[...] a Guardia de Hierro se dissolveu após a morte de Perón [...], incapaz de administrar uma herança que teria que defender com armas e com sangue nos meses seguintes. Isso também salvou a vida dos meus pais e a minha [14]. Seus companheiros que decidiram se juntar a outras organizações para continuar a militância foram assassinados e desaparecidos, e outros foram embora do país, mas o resto também viveu um doloroso processo de adaptação e uma espécie de exílio interior, em que tiveram que assistir ao fracasso de uma experiência revolucionária à qual a ditadura daria um fim definitivo. Quem continuou depois desse fim - ou recebeu ordens para continuar - foi assassinado [...]. (PRON, 2018, p. 134) 
Por meio desse relato, o leitor toma conhecimento de fatos históricos relevantes envolvendo os pais e os outros militantes que tiveram fins trágicos devido ao caos argentino das décadas de 1970/1980. Ao transmitir essas memórias, o protagonista revela um dever de pósmemória, repassando às gerações posteriores feridas que não são suas, mas que também o afetam, tornando-se um pós-memorialista.

Com isso, o narrador registra o passado e o arquiva, atuando, também, como um arquivista. Assim, a literatura de Pron se configura como um arquivo, um lugar de memória (NORA, 1993), que revela uma face do passado argentino. Vale ressaltar que quando nos referimos à literatura como forma de arquivo é claro que não podemos deixar de considerar as produções historiográficas e jornalísticas, que também funcionam como atos de memória de grande relevância. Mas, conforme salienta Figueiredo (2017), a literatura cumpre o papel de suplemento a esses arquivos que são áridos e de difícil leitura, possibilitando a ficcionalização do passado, a fim de que ele possa ser conhecido, sentido, compreendido, refletido, repensado. Afirma:

[...] só a literatura é capaz de recriar o ambiente de terror vivido por personagens afetados diretamente pela arbitrariedade, pela tortura, pela humilhação, pois, como afirma Jacques Ranciére (2009, p. 58), "o real precisa ser ficcionalizado para ser pensado”. Numerosos críticos e pensadores têm salientado tanto a necessidade quanto as possibilidades da ficção em recriar, através da imaginação e da liberdade composicional, não aquilo que realmente aconteceu, o que é impossível, [...], mas algo que possa evocar o que pensaram, sentiram ou sofreram os personagens. (FIGUEIREDO, 2017, p. 43).

Desse modo, através de $\mathrm{O}$ espirito dos meus pais continua a subir na chuva, temos acesso a histórias autênticas sobre pessoas que lutaram pela liberdade argentina; histórias de pessoas que foram diretamente afetadas por esse regime, mesmo quando ele já havia terminado (Chacho, o narrador, Alberto Burdisso); histórias que, ainda que coloridas de ficção, nos permitem conhecer parte desse passado, imaginá-lo, recordá-lo e refletir sobre ele e sobre os impactos ele teve sobre os que ficaram.

Assim, Pron escreve sobre o passado com vistas no futuro, com o intuito de transmitir às próximas gerações o legado de sua geração anterior, atuando como um arquivista, um herdeiro e um porta-voz de seus pais. Ao escrever esse texto, o autor recorda, transforma, repensa e discute questões sociais e individuais a partir da rememoração e da ficção, de maneira a armazenar e a difundir memórias, tarefa muito necessária na contemporaneidade. Dessa maneira, Pron escreve para fazer lembrar para si, para os pais e para outros; escreve para que o que os pais e milhares de argentinos viveram não seja esquecido; escreve para que o espírito revolucionário de seus pais prevaleça na memória coletiva e "continue a subir na chuva até tomar o céu de assalto" (PRON, 2018).

\section{Referências}

ASSMANN, A. Espaços da recordação: formas e transformações da memória cultural. Tradução de Paulo Soethe. Campinas, SP: Editora da Unicamp, 2011. 
BERGSON, H. Matéria e Memória: ensaio sobre a relação do corpo com o espírito. Tradução de Paulo Neves. 4a ed., São Paulo: Editora WMF Martins Fontes, 2010.

BERND, Z. Notas para uma teoria da transmissão. In: A persistência da memória: romances da anterioridade e seus modos de transmissão intergeracional. Porto Alegre: BesouroBox, 2018.

BORGES, J. L. Ficciones. In: . Obras Completas. Buenos Aires: Emecé Editores, 1974.

BOSI, E. Memória e Sociedade: lembranças de velhos. 3a ed., São Paulo: Companhia das Letras, 1994.

CAPELATO, M. H. Memória da ditadura militar argentina: um desafio para a história. Revista Clio: Revista de Pesquisa Histórica, Recife, n. 24, pp. 61-81, 2006.

DERRIDA, J. Mal de Arquivo: uma impressão freudiana. Tradução de Cláudia de Moraes Rego. Rio de janeiro: Relume Dumará, 2001.

DOUBROVSKY, S. Fils. Paris: Grasset, 1977.

FIGUEIREDO, E. A literatura como arquivo da ditadura brasileira. Rio de Janeiro: 7 Letras, 2017.

GALEANO, E. El libro de los abrazos. Madrid: Siglo XXI, 2000.

LE GOFF, J. A ordem da memória. In: . História e Memória. Tradução de Bernardo Leitão. Campinas-SP: Editora da Unicamp, 2013.

NORA, P. Entre memória e história: a problemática dos lugares. Projeto História: revista do Programa de Estudos Pós-Graduados em História e do Departamento de História da Pontifícia Universidade Católica de São Paulo, São Paulo, n. 10, pp. 7-28, 1993.

NOVARO, M. PALERMO, V. A Ditadura Militar Argentina 1976-1983: Do Golpe de Estado à Restauração Democrática. Tradução de Alexandra de Mello e Silva. São Paulo: Editora da Universidade de São Paulo, 2007.

ORWELL, G. 1984. Tradução de Alexandre Hubner, Heloísa Jahn. São Paulo: Companhia das Letras, 2009.

PASCUAL, A. L. Terrorismo de estado: a Argentina de 1976 a 1983. Brasília: Universidade de Brasília, 2004.

POLLAK, M. Memória e Identidade Social. Estudos Históricos, Rio de Janeiro, v. 5, n. 10, pp. 200-212, 1992.

PRON, P. O espírito dos meus pais continua a subir na chuva. Tradução de Gustavo Pacheco. São Paulo: Todavia, 2018.

RICOEUR, P. A memória, a história, o esquecimento. Tradução de Alain François. Campinas-SP: Editora da Unicamp, 2007.

SARLO, B. Tempo passado: cultura da memória e guinada subjetiva. Tradução de Rosa Freire d'Aguiar. São Paulo: Companhia das Letras; Belo Horizonte: UFMG, 2007.

SOUZA, R. Memória e Imaginação. In: BERND, Z. (org.). Dicionário das mobilidades culturais: percursos americanos. Porto Alegre: Literalis, pp. 247-268, 2010.

TODOROV, T. Los abusos de la memoria. Tradução de Miguel Salazar. Barcelona: Ediciones Paidós Ibérica, 2000. 
Recebido em: 19/04/2020

Aceito em: 13/06/2020 